\title{
Paradigma Pendidikan Anak dalam Keluarga di Era Digital (Perspektif Pendidikan Islam)
}

\author{
Tian Wahyudi \\ Universitas Islam Indonesia \\ e-mail: tianwahyudi@uii.ac.id
}

\begin{abstract}
This article discusses the paradigm of child education in the family in the Digital Age in the perspective of Islamic education. Digital technology as the main feature of the digital era has two different sides, one side provides benefits, on the other hand causes damage. The benefits include ease of various aspects of the information needed, the presence of a variety of educational media and other positive content. Whereas the damage includes the strengthening of instant culture, the ease of children to access various inappropriate content, the rise of various criminalization in cyberspace etc. The paradigm of family education built in the digital era should pay attention to the reality of the present condition. This refers to the reality of the current generation that is very close to the digital world. Therefore, the educational approach should also be adapted to the conditions of children in this era. The important efforts that parents can make towards their children's education in the family are: (1) able to understand the potential and development of children; (2) able to understand the educational content that must be transmitted to their children; (3) able to recognize digital media both aspects of benefits and negative impacts; (4) able to use digital media as a means of education.
\end{abstract}

Keyword: child education, family, digital era

\begin{abstract}
Abstrak
Artikel ini membahas paradigma pendidikan anak dalam keluarga di Era Digital dalam perpektif pendidikan Islam. Teknologi digital sebagai cirri utama era digital memiliki duasisi yang berbeda, satu sisi memberikan manfaat, di sisi lain menimbulkan madharat. Manfaatnya mencakup kemudahan terhadap berbagai aspek informasi yang dibutuhkan, hadirnya beragam media edukatif, dan berbagai konten positif lainnya. Sedangkan madharatnya meliputi semakin kuatnya budaya instan, kemudahan anak untuk mengakses berbagai konten yang tidak layak, maraknya berbagai kriminalisasi dalam dunia maya dsb. Paradigma pendidikan keluarga yang dibangun di era digital seyogyanya memperhatikan realitas kondisi kekinian. Hal ini mengacu kepada realitas generasi saat ini yang sangat dekat dengan dunia teknologi. Dengan demikian, pendekatan pendidikannya pun seharusnya dapat disesuaikan dengan kondisi anak di era ini. Adapun upaya yang dapat dilakukan orang tua dalam pendidikan anak di dalam keluarga yaitu: (1) mampu memahami potensi dan perkembangan anak; (2) mampu memahami muatan pendidikan yang harus ditrasmisikan kepada anaknya; (3) mampu mengenali media digital baik aspek mafaat maupun dampak negatifnya; (4) mampumenggunakan media digital sebagai sarana pendidikan.
\end{abstract}

Kata kunci: pendidikan anak, keluarga, era digital 


\section{Pendahuluan}

Pesatnya perkembangan teknologi digital dewasa ini menunjukan bahwa dunia saat ini telah memasuki era baru yang dikenal dengan era digital.Transformasi dari teknologi mekanik dan elektronik analog ke teknologi digital, lahirnya internet, dan pesatnya perkembangan jejaring sosial seperti whatsApp, Facebook, Instragram, twitter, line dan sebagainya adalah gambaran nyata telah lahirera baru tersebut.Di era digital inisetiap orang dapat mengakses, memberikan, menyebarkan, berkomunikasi, dan melakukan berbagai aktivitas secara daring (online).Berbagai media dapat digunakan secara bebas dan luas. Didukung lagi dengan akses terhadap informasi yang tak terbatas. Seseorang dalam hitungan menit, bahkan detik dapat mengabarkan informasi ke negaralain dan dengan waktu yang sama pula dapat mengetahui informasi dari belahan bumi lain.

Penggunaan media digital saat ini seolah tidak dapat dilepaskan dari kehidupan manusia modern. Menurut Asosiasi Penyelenggara Jasa Internet Indonesia (APJII), pada tahun 2017 jumlah pengguna internet semakin meningkat pesat. Pada tahun 2016 masyarakat Indonesia yang menggunakan internet sebanyak 10,56 juta jiwa dan meningkat jumlahnya pada tahun 2017 mencapai 143,26 juta jiwa atau setara dengan 54,68 persen dari total jumlah penduduk Indonesia. ${ }^{1}$ Ini artinya lebih dari setengah populasi di Indonesia telah terkoneksi dengan Internet.

Dunia teknologi informasi yang menawarkan aneka ragam kemudahan dengan budaya otomatisasi, disatu sisi menawarakan kemanfaatan bagi manusia, namun disisi lain juga tidak sedikit menimbulakan kemadharotan bagi manusia itu sendiri.Banyak pekerjaaan-pekerjaan yang sebelumnya sangat bergantung pada orang lain, menuntut waktu tidak sedikit, energi yang besar dan kemampuan fisik yang prima, dengan hadirnya system atau perangkat digital yang menawarkan solusi yang seba otomatis, ketergantungan tersebut dapat dikurangi. Kemudahan tersebut semakin hari tanpa disadari telah membembentuk budaya baru, yakni budaya instan dan individualis. Tidak sedikit ditemukan di jalan, di angkot, bahkan di tempat makan dalam satu meja orang sibuk dengan gadget atau hp-nya masing-masing. Kondisi ini juga dapat dilihat dalam kehidupan keluarga. Anggota dalam satu keluarga yang sejatinya ketika berkumpul mereka berkomunikasi secara akrab face to face tentang suatu topik tertentu, namun yang terjadi mereka sibuk dengan hp atau gadgetnya masing-masing.

Realitas lain yang juga merupakan masalah serius di era digital ini dapat dijumpai dalam dunia maya,seperti penyebaran berita hoax, perundungan maya, ujaran kebencian, prostitusi online, eksploitasi seksual danpornografi, perdagangan anak dan lain-lain. Padahal anak-anak saat ini tidak dapat dipungkiri,banyak menghabiskan waktu mereka dengan media digital. Sampai dengan tahun 2016, sebagaimana dipaparkan dalam majalah Swara Cita, bahwa

${ }^{1}$ Siaran Pers No. 53/Hm/Kominfo/02/2018 tanggal 19 Februari 2018, Tentang Jumlah Pengguna Internet 2017 Meningkat, Kominfo akan Terus Lakukan Percepatan Pembangunan Broadband, diakses pada tanggal 24-01-2019 
anak-anak Indonesia menghabiskan waktu sebanyak 7,5 jam per hari di depan tv, komputer, dan gadget. ${ }^{2}$

Dalam kaitannya dengan pendidikan anak, era digital sejatinya menawarkan beragam peluang kemudahan, namun besarnya ancaman juga tidak dapat dipandang sebelah mata. Anak-anak sebagai generasi bangsa dan umat sekaligus, perlu mendapat perhatian yang serius dalam upaya membangun pribadi yang siap menghadapi tantangan zaman. Oleh karenanya, penting juga bagi pendidik, khususnya orang tua sebagai pendidik utama, memahami kondisi dan realitas yang terjadi saat ini.

Bertolak dari pemikiran di atas, penulis dalam artikel ini membahas paradigma pendidikan Islam terhadap pendidikan anak dalam keluarga di Era Digital. Hal ini penting untuk dikaji lebih dalam untuk memahami peran pendidikan keluarga, problematika anak masa kini, dan paradigma pendidikan Islam dalam keluarga menghadapi tantangan pesatnya perkembangan teknologi.

\section{Era Digital dan Lahirnya Generasi Digital Native}

Terma digital native merupakan istilah yang digunakan Marc Prensky untuk menggambarkan generasi yang lahir dengan kondisi perkembangan teknologi yang sangat pesat. Mereka hidup dan menghabiskan waktunya dengan menggunakan dan dikelilingi oleh komputer, videogame, pemutar musik digital, kamera video, ponsel, dan semua mainan dan alat lain dari era digital. ${ }^{3}$ Orangorang yang masuk generasi ini beranggapan bahwa teknologi digital merupakan bagian yang integral dengan kehidupan mereka. Hal ini terasa disaat merekatidak memiliki atau memperoleh akses terhadap internet. ${ }^{4}$

Bila dilihat dari sudut usia kelahiran, generasi digital adalah generasi yang lahir pada tahun 1993 atau pendapat lain yaitu 1994 sampai sekarang. ${ }^{5}$ Ada juga yang menggolongkan bahwa mereka yang lahir tahun 1982 termasuk digital native. ${ }^{6}$ Digital native dalam istilah lain disebut juga sebagai the net. generation, yaitu suatu istilah untuk menggambarkan generasi yang lahir di tengah pertumbuhan komputer dan internet yang sangat pesat. ${ }^{7}$

Berkaitan dengan penentuan generasi digital nativ berdasarkan usia kelahiran, Akcayir menjelaskan,bahwa usia atau tahun lahir semata tidak dapat dijadikan faktor penentu seseorang disebut sebagai digital native. Walaupun dia lahir di periode 1980 (masa kelahiran digital native menurut Akcayir) namun jika

${ }^{2}$ Tim Redaksi Majalah Swara Cita, “Anak Indonesia,"Majalah Swara Cita: Generasi Digital, (DigdayaDinamikaPublika, 2016), 7.

${ }^{3}$ Marc Prensky, Digital Natives, Digital Immigrants Part 1, On the Horizon Vol. 9 Issue: 5 (Oktober, 2001), 1.

${ }^{4}$ PurwaniIstiana ,“Gaya Belajar Dan Perilaku Digital Native Terhadap Teknologi Digital dan Perpustakaan,'Prosiding Seminar Nasional: Kreatifitas Pustakawanpada Era Digital dalam Menyediakan Sumber Informasi bagi Generasi Digital Native, (UNPAD Press,2016), 345.

${ }^{5}$ Jonner Hasugian, Perpustakaan Digital dan Digital Natives, makalah yang disampaikanpada seminar dan workshop nasional Pemberdayaan Repository... di U.H. Nommensen Medan, 12.http://repository.usu.ac.id/handle/123456789/64595 di akses pada $4 / 02 / 2019$

6 Riana Mardina, "Potensi Digital Natives Dalam Representasi Literasi Informasi Multimedia Berbasis Web Di PerguruanTinggi,"Jurnal Pustakawan Indonesia Vol 11 No. 1 (2011),7.

${ }^{7}$ JonnerHasugian, Perpustakaan Digital...,12. 
pada masa perkembangannya tidak memiliki akses terhadap teknologi, jauh dari lingkungan teknologi, dan tidak banyak menghabikan waktu dengan teknologi maka mereka bukanlah digital native. ${ }^{8}$ Dengan kata lain, sejauh mana hubungan dan pengalaman dengan dunia digital adalah faktor penentu dari penyematan terhadap genarasi native digital.

Kendati demikian,tidak dapat dipungkiri, bahwa konektivitas antara dunia digital dengan dunia anakdewasa ini semakin hari-semakin kuat. Pesatnya teknologi informasi dan semakin meluasnya penggunaan media digital, tak terkecuali oleh anak-anak adalah gambaran yang menunjukan besarnya pengaruh dunia digital terhadap anak-anak.Karenanya, perbedaan penting yang terlihat dari generasi ini adalah kemampuannya dalam penggunaan beragam teknologi informasi. Kelincahan dalam menggunakan berbagai produk dan fasilitas teknologi yang menyajikan beragam fitur menarik adalah kekhasan mereka.

Adapun ciri generasi digital, sebagaimana dijelaskan dalam buku Seri Pendidikan Orang Tua: Mendidik Anak di Era Digital yang diterbitkan Kementrian Pendidikan dan Kebudayaan, antara lain: ${ }^{9}$

1. Menunjukan eksistensi diri dengan beragam media digital, seperti Facebook, Twitter, Path, Instagram, Youtube.

2. Menunjukan keterbukaan, blak-blakan, dan berpikir lebih agresif

3. Kebebasan berekspresi, tidak ingin diatur dan dikekang. Internet bagi mereka menawarkan kebebasan tersebut.

4. Berkaitan dengan proses belajar, generasi digital menggunakan mesin pencari seperti Google, Yahoo dan sebagainya untuk mendapatkan informasi yang diinginkan. Kemampuan belajar mereka lebih cepat karena berbagai informasi ada di ujung jari mereka.

Ciri atau karakteristik di atas seyogyanya menjadi bahan kajian dan perhatian bagi para pendidik tak terkecuali orang tua sebagai pendidik utama. Kajian yang dimaksud adalah kajian berkaitan dengan sikap dan dampak dari kedekatan anak-anak dengan dunia digital. Sementara maksud dari perhatian adalah bimbingan dan pengawasan orang tua terhadap anak-anak di era digital ini. Dengan pendekatan yang mengacu kepada perkembangan zaman inilah diharapakan orang tua dapat mendidik anak dengan pendekatan pendidikan yang tepat. Dengan upaya tersebut harapannya, pendidikan dalam keluarga dapat melahirkan generasi shaleh yang siap menghadapi tantangan zaman.

\section{Era digital: Pengaruh dan Dampaknya TerhadapAnak-anak}

Sebagaimana dijelaskan di atas, bahwa saat ini, banyak anak yang telah fasih menggunakan media digital. Praktis dan kemudahan untuk dibawa ke mana saja merupakan salah satu alasan pengguna tidak dapat lepas dari media tersebut, seperti smart phone, tablet, netbook dsb yang bentuknya kecil. Anakanak dari berbagai usia,dengan mudah menggunakan gawai di mana-mana, di berbagai tempat untuk beragam keperluan, seperti, bermain "game", melihat dan

\footnotetext{
${ }^{8}$ Purwani Istiana ,Gaya Belajar...,346.

9 Tim Kementrian Pendidikan dan Kebudayaan, Seri Pendidikan Orang Tua: Mendidik Anak di Era Digital, (Jakarta: Kementrian Pendidikan dan Kebudayaan, 2016) ,11-12.
} 
membuat video, memotret, mencari informasi melalui mesin pencari, maupun berselancar di dunia maya melalui media social dan lain-lain.

Teknologi digital pada dasarnya sama seperti media atau alat pada umumnya, memiliki potensi kemanfaatan atau kemadharatan. Sepertihalnya pisau dapat menjadi sangat bermanfaat bila digunakan oleh ibu rumah tangga di dapur, namun menjadi sangat berbahaya jika diberikan kepada balita atau anak kecil yang belum memahami fungsi pisau. Teknologi, bila tidak digunakan secara proporsional dan dimanfaatkan dengan bijaksana, dapat menjadi sangat berbahaya.

Diantara manfaat media digital bagi anak paling tidak terdapat lima hal:1) sebagai sumber informasi, media digital mampu mempercepat akses terhadap informasi yang dibutuhkan, seperti berita terkini, hobi, informasi lokasi destinasi jika ingin berpergian, informasi berbagai peristiwa di daerah atau negara lain dsb.; 2) untuk belajar/tutorial, media digital dapat digunakan untuk mencari atau mendapatkan materi pelajaran, bertukar informasi terkait tugas atau materi, mengkaji lebih lanjut materi yang diajarkan di sekolah melalui browsing di internet dan dapat juga untuk mengikuti kelompok atau group belajar di media sosial; 3) Kemudahan dalam berkomunikasi baik dengan keluarga maupun teman walaupun berjarak jauh; 4) Sharing hal positif melalui media social, blog dsb.; 5) memperluas jaringan social, melalui media social anak-anak dapat mendapatkan teman di dunia maya.

Namun demikian, disamping manfaat, terdapat pula beragam masalah dengan hadirnya dunia digital tersebut. Kementrian Pendidikan Jepang sebagaimana diberitakan media online New York Daily News pada 29 Agustus 2013 mengabarkan, bahwa sekitar 518.000 anak-anak Jepang yang berusia antara 12 dan 18 tahun telah mengalami kecanduan Internet. Upaya penyelesaian masalah tersebut, dilakukan pemerintah jepang adalah dengan mengadakan program kamp "puasa" Internet. Program tersebut bertujuan untuk membantu mereka memutuskan hubungan dari dunia online. Mereka didorong untuk dapat berkomunikasi dengan anak-anak lain dan berpartisipasi dalam permainan, olahraga tim, dan kegiatan lainnya dalam dunia nyata. ${ }^{10}$

Adapun dampak yang ditimbulkan darikecanduan online dikatakan Yomiuri Shimbun, dapat menyebabkan gangguan tidur dan makan serta trombosit vena dalam, pembekuan darah di kaki bagian bawah atau paha. Lebih lanjut dia mengatakan terlalu lama berselancar dalam dunia maya juga dapat menyebabkan peningkatan risiko depresi, dan obesitas anak, serta mengganggu pekerjaan sekolah, dangangguan tidur. ${ }^{11}$

Disadari atau tidak ketika berselancar di dunia maya, anak-anak maupun dewasa seringkali menemukan atau mendapatkan konten atau informasi yang tidak layak. Pornografi adalah salah satu konten yang sering muncul. Tidak sedikit orang tua yang khawatirterhadap sejumlah situs web yang memuat informasi seksual yang vulgar. Oleh karena itu, banyak keluarga merasa khawatir dengan kemudahan akses terhadap fasilitas internet yang

${ }^{10}$ Victoria Taylor, Japan to launch 'fasting' camps for Internet-addicted students, dalam http://www.nydailynews.com/life-style/diakses pada tanggal 6 Februari 2019.

${ }^{11}$ Ibid. 
memungkinkan anak dapat mengakses dengan mudah konten tak layak tersebut. ${ }^{12}$

Dalam buku Kajian Dampak Penggunaan Media Sosial Bagi Anak Dan Remaja, Endah Triastuti (dkk) menyajikan beberapa data hasil studi yang dilakukan oleh beberapa institusi berkaitan dengan aktivitas dan dampak media online terhadap anak, antara lain:13

1. Data hasil studi Badan Pusat Statistik (BPS) tahun 2010 - 2014: sebanyak 80 juta anak-anak telah mengakses pornografi online dan jumlah tersebut terus meningkat menjadi $90 \%$.

2. Data hasil studi yang dilakukan oleh Komisi Perlindungan Anak Indonesia (KPAI) tahun 2011-2014: sebanyak 932 khasus pornografi dan kejahatan dunia maya menjadikan anak-anak sebagai target utama.

3. Data hasil studi End Child Prostitution, Child Pornography \& Trafficking Of Children For Sexual Purposes Indonesia(ECPAT INDONESIA) tahun 2010- 2015: sebanyak 35 anak mengalami ekpsloitasi seksual di ranah maya.

4. Data hasil studi Indonesia Sejiwa Foundation: sebanyak 2 dari 10 anak Indonesia yang mengakses sosial media mengalami perundungan maya.

5. Studi Komenkominfo bersama dengan UNICEF pada tahun 2014: anak-anak dan remaja berbohong terkaitusia mereka dengan tujuan agar dapat mengakses situs internet. Studi ini juga melaporkan bahwa anak dan remaja berkomunikasi dengan orang asing ketika di dunia maya.

Dari penjelasan di atas dapat disimpulkan, bahwa terdapat potensi nilai manfaat dan madharatdalam pesatnya perkembangan dunia digital. Karenanya penting untuk dilakukan ikhtiar melalui edukasi yang baik terhadap masyarakat. Pemahaman masyarakat terhadap literasi teknologi yang memadai adalah upaya yang perlu menjadi salah satu prioritas dalam rangka membangun budaya digital yang konstruktif, bukan merusak, apalagi menghancurkan. Bila hal tersebut tercapai, maka peningkatan pengguna teknologi digital tidak sematamata peningkatan kuantitas, namun menjadi peningkatan kualitas. Dengan demikian, bukan tidak mungkin bila hal tersebut dilakukan secara kontinyu dan konsisten, Indonesia ke depan akan menjadi Negara maju.

\section{Tanggung Jawab Orang Tua Terhadap Pendidikan Anak}

Dalam pandangan Islam, anak bagi orang tua, disamping anugerah dia juga merupakan amanah. Kelak setiap orang tua akan dimintai pertanggung jawaban terhadap apa yang dia perbuat terhadap anaknya. Abu Hafizh Suwaid mengutip perkataan Ibnu Qayyim yang mengatakan, "sebagian ulama berpendapat bahwa sesungguhnya Allah Swt. bertanya kepada orang tua

\footnotetext{
${ }^{12}$ Nasrun Faisal, "Pola Asuh Orang Tua dalam Mendidik Anak Di Era Digital,"Jurnal AnNisa', Volume IX Nomor 2 (Desember, 2016),133.

${ }^{13}$ EndahTriastuti, Dimas Adrianto Indra Prabowo, dan Akmalia Nurul, 2017, Kajian Dampak Penggunaan Media Sosial Bagi Anak Dan Remaja, (Depok: Pusat Kajian Komunikasi, FISIP Universitas Indonesia),9-10.
} 
tentang anaknya di hari kiamat sebelum bertanya kepada anak tentang orang tuannya. Jika orang tua memiliki hak atas anaknya, maka demikian pula sang anak memiliki hak atas orang tuannya."14 Dalam hal ini Nabi Muhmammad Saw. menegaskan, bahwa setiap orang akan ditanya tentang apa yang menjadi tanggung jawabnya, termasuk perannya sebagai orang tua. Dari Ibnu Umar r.a, Rasulullah Saw bersabda:

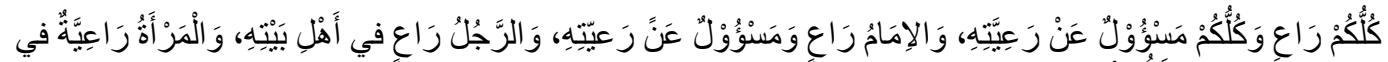

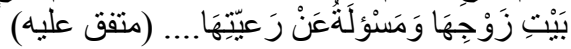

"Setiap kalian adalah pemimpin dan setiap kalian bertanggung jawab atas apa yang dipimpin. Seorang pemimpin bertanggung jawab terhadap yang dipimpinnya. Seorang laki-laki pemimpin dalam keluarganya dan dia bertanggung jawab terhadap yang dipimpinanya. Seorang wanita adalah pemimpin di rumah suaminya dan dia bertanggung jawab terhadap yang dipimpinya....(H.R. Bukhari dan Muslim).

Terdapat juga hadits lain yang diriwayatakan Ibnu Hiban dan Nasai dari Anas bin Malik bahwa Nabi Saw. bersabda:

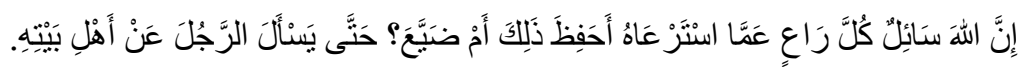

"Sesungguhnya Allah akan bertanya kepada setiap pemimpin tentang apa yang dipimpinnya, apakah dia menjaganya ataukan menyia-nyiakan? hingga Dia bertanya kepada orang itu atas keluarganya.

Kedua hadist di atas menunjukan bahwa ada peran dan tugas setiap orang terhadap keluarganya. Seorang ayah memiliki tugas dan kewajiban terhadap keluargannya. Begitupun seorang ibu, dia memiliki tanggung jawab terhadap keluarganya. Orangtua dalam institusi keluarga, memiliki tanggung jawab penuh terhadap anak-anaknya. Diantara kewajiban pokok orang tua terhadap anaknya adalah memberikan pengasuhan dan pendidikan yang baik. Allah berfirman dalam Al-Qur'an surah At-Tahrim [66]: 6 yang berbunyi:

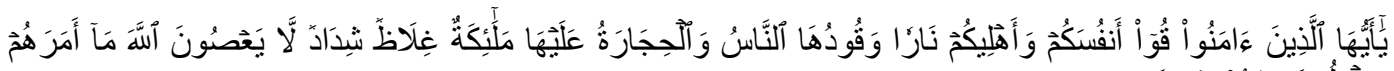

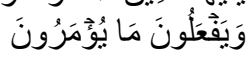

"Hai orang-orang yang beriman, peliharalah dirimu dan keluargamu dari api neraka yang bahan bakarnya adalah manusia dan batu; penjaganya malaikat-malaikat yang kasar, keras, dan tidak mendurhakai Allah terhadap apa yang diperintahkan-Nya kepada mereka dan selalu mengerjakan apa yang diperintahkan."

Kalimat "quu 'anfusakum wa ahlikum naran" pada ayat di atas yang berarti "peliharalah dirimu dan keluargamu dari api neraka" dimaknai oleh Ali bin Abi Thalib dengan, "allimu 'anfusakum wa ahlikum khairan", yang berarti, "ajarilah diri kalian dan keluarga kalian kebaikan". Sementara itu Muqatil menafsirkan kalimat tersebut dengan: "hendaklah bagi seorang muslim agar memerintahkan dirinya dan keluarganya untuk melakukan kebaikan, dan melarang berbuat kemaksiatan". ${ }^{15}$ Muqatil juga berpendapat, bahwa setiap muslim memiliki kewajiban untuk mengajari keluarganya, kerabatnya dan juga budaknya

${ }^{14}$ Muhammad Nur Abdul Hafizh Suwaidi, Prophetic Parenting: Cara Nabi Mendidik Anak, terj. Farid Abdul Aziz Qurusy, (Yogyakarta: Pro-U Media, 2012),50.

${ }^{15}$ Ibid.,49. 
berbagai hal yang berkenaan dengan hal-hal yang diwajibkan dan dilarang bagi mereka. ${ }^{16}$

Pendidikan adalah hak anak yang harus ditunaikan orang tua. Kewajiban orang tua bukan hanya sekedar memberikan makanan dan pakaian kepada anak-anaknya, namun memberikan pendidikan yang optimal kepada mereka juga merupakan hal yang pokok.Pendidikan yang baik dapat mengantarkan seorang anak menjadi pribadi yang baik. Oleh karenanya, penting bagi orang tua untuk memahami pertumbuhan dan perkembangan anak sekaligus pemahaman dan keterampilan yang memadai tentang bagaimana pendidikan yang tepat bagi anak mereka.

Tujuan pendidikan itu sendiri dalam Islam adalah mencetak generasi shaleh. Generasi yang tindakan dan perilakunya dijiwai dan dilandasi oleh iman dan taqwa, sertapenghambaan sepenuhnya kepada Allah. Tujuan pendidikan tersebut menurut M. Natsir sejatinya bermaksud merealisasikan tujuan hidup muslim itu sendiri yakni totalitas dalam menghambakan diri kepada Allah. Hal ini sesuai dengan maksud firman Allah dalam surat al-Dzariyat [51] ayat 56, yang menyatakan bahwa tujuan penciptaan manusia yaitu pengabdian (dalam pengertian yang luas) kepada Allah. ${ }^{17}$

Tugas orang tua adalah berupaya seoptimal mungkinagar anaknya dapat menjadi pribadi shaleh sebagaimana tujuan pendidikan Islam itu sendiri. Keluarga adalah tempat dimana anak tumbuh dan berkembang. Peran dan pengaruh keluarga terhadap pribadi anak sangat besar. Lingkungan pertama bagi seorang anak adalah keluarga. Maka peran dan tugas orang tua dalam keluarga adalah memberikan pendidikan yang mengarah kepada pembentukan pribadi anak yang shaleh.

Untuk mencapai tujuan tersebut, penting juga disadari oleh orang tua bahwaanak terlahir dengan membawa beragam potensi baik (fitrah) yang perlu dikembangkan. Tugas orang tua adalah membantu anak untuk mengembangkan beragam potensi tersebut. Karenanya, orang tua harus berusaha keras agar potensi tersebut dapat berkembang dengan baik dan optimal.

Dalam buku Tarbiyatul Aulad fi al-Islam,Abdulllah Nasih Ulwan menjelaskan, bahwa ada tujuh tanggung jawab pendidik termasuk orang tua terhadap anaknya, yaitu: 1). tanggung jawab pendidikan iman, 2). tanggung pendidikan akhlak, 3). tanggung jawab pendidikan fisik, 4). tanggung jawab pendidikan rasio, 5). tanggung jawab pendidikan psikis, 6). tanggung jawab pendidikan sosial, 7). tanggung jawab pendidikan seksual. ${ }^{18}$

Pendidikan Iman yang dimaksud Nasih Ulwan adalah mengikat anak dengan dasar-dasar keimanan sejak ia mengerti, membiasakannya dengan rukun Islam sejak ia memahami, dan mengajarkannya dasar-dasar syariat sejak usia tamyiz. ${ }^{19}$ Sementara yang dimaksud pendidikan akhlaqadalah serangkaian prinsip dasar akhlaq dan keutaman sikap serta watak yang harus dimiliki dan dijadikan kebiasaan oleh anak sejak dini hingga ia menjadi seorang mukallaf, yakni siap mengarungi lautan kehidupan. ${ }^{20}$ Adapun yang dimaksud pendidikan

\footnotetext{
${ }^{16}$ IbnuKatsir, tafsir Ibnu Katsir dalam E-Book "Ayat”, surat at-Tahrimayat 6.

${ }^{17}$ Toto Suharto, Filsafat Pendidikan Islam, (Yogyakarta: Ar-Ruzz, 2006),113.

${ }^{18}$ Abdullah Nasih Ulwan, Pendidikan Anak Dalam Islam Jilid 1, terj. Jamaludin Miri, (Jakarta: Pustaka Amani, 2002), 164.

${ }^{19}$ Ibid., 165.

${ }^{20}$ Ibid., 193.
} 
fisik yaitu berkaitan dengan dasar-dasar ilmiah yang digariskan Islam dalam mendidik fisik anak-anak. Hal ini dimaksudkan agar mereka tumbuh dewasa dengan kondisi fisik yang kuat, sehat, dan bersemangat. ${ }^{21}$

Berkaitan pendidikan rasio, Nasih Ulwan menjelaskan bahwa pendidikan rasio adalah upaya pembentukan dan pembinaan kemampuan berpikir anak dengan segala sesuatu yang bermanfaat seperti ilmu syariah, peradaban ilmiah, kesadaran berpikir dan berbudaya.22Sedangkan maksud dari pendidikan psikis adalah mendidik anak semenjak ia mampu berpikir untuk bersikap berani, terbuka, mandiri, suka menolong, mampu mengendalikan amarah, senang terhadap keutamaan jiwa dan moral secara mutlak. ${ }^{23}$ Selanjutnya pendidikan sosial, dijelaskan oleh Ulwan sebagai bentuk pendidikan anak sejak kecil agar terbiasa menjalankan perilaku sosial yang utama, dasar-dasar kejiwaan yang mulia yang bersumber pada aqidah Islamiyah yang abadi dan kesadaran iman yang mendalam, agar di tengah-tengah masyarakat kelak mampu tampil bergaul dan bersosial dengan adab yang baik, memiliki keseimbangan akal yang matang dan tindakan yang bijaksana. ${ }^{24}$

Pendidikan seksual yang juga merupakan salah satu tanggung jawab orang tua adalah upaya pengajaran, penyadaran, dan penerangan tentang masalah-masalah seksual kepada anak sejak ia mengenal segala masalah yang berkenaan dengan naluri seks dan perkawinan. Dengan demikian, bila anak sudah beranjak tumbuh menjadi seorang pemuda dan telah memahami berbagai permasalahn kehidupan, dia telah memiliki pemahaman berkaitan dengan apa yang diharamkan dan apa yang dihalalkan. Lebih lanjut Ulwan menjelaskan, dengan pendidikan tersebut, anak mampu menerapkan tingkah laku islami sebagai akhlak dan kebiasaan hidup, serta tidak diperbudak syahwat dan tenggelam dalam gaya hidup hedonis. ${ }^{25}$

Orang tua sebagai pendidik, memiliki tanggung jawab multidimensial, karena disamping harus memahami perkembangan anak, mereka juga dituntut untuk memahami tanggung jawab terhadap pendidikan mereka yang multidimensi sebagaimana tersebut di atas. Tanggung jawab pendidikan tersebut pada dasarnya dengan mempertimbangkan dimensi yang terdapat dalam diri anak. Oleh karenanya, materi pendidikan yang harus diinternalisasikan kepada anak merupakan satu kesatuan utuh, menyeluruh dan tanpa memisahkan antara satu dengan yang lainnya. ${ }^{26}$

Beragamnya dimensi pendidikan yang menjadi tanggung jawab orang tua tersebut sejatinya adalah berlandaskan kepada keragamanya potensi yang dimiliki anak. Anak membutuhkan arahan dan bimbingan yang tepat dalam rangka menjadikan potensi-potensi yang dimilikinya menjadi kekuatan yang mulia dan berdaya guna. ${ }^{27}$

\footnotetext{
${ }^{21}$ Ibid., 245.

${ }^{22}$ Ibid., 301 .

${ }^{23}$ Ibid., 363.

${ }^{24}$ Ibid., 435.

${ }^{25}$ Abdullah Nasih Ulwan, Pendidikan Anak dalam Islam Jilid 2, terj. Jamaludin Miri, (Jakarta: Pustaka Amani, 2002), 1.

${ }^{26}$ Khasnah Sya'idah, "Pemikiran Pendidikan Anak Abdullah Nasih Ulwan",Disertasi Doktoral, (Jakarta:Universitas Islam Negeri Syarif Hidayatullah,2005),142.

${ }^{27}$ Ibid., 143.
} 
Dari uraian di atas dapat dipahami bahwa tugas orang tua terhadap anak sangat besar. Dibutuhkan ilmu yang memadai untuk menjalankan tugas tersebut. Disamping itu,tugas pendidikan juga sejatinya adalah tugas pendewasaan, sehingga membutuhkan waktu yang lama dan bertahap. Karenanya dibutuhkan kesungguhan dan kesabaran seorang pendidik agar tercapai hasil yang optimal.

Pendidikan anak adalah langkah awal dalam upaya peningkatan kualitas umat. Tanpa melalui tahapan tersebut tidak mungkin akan mencapai hasil optimal. Anak dengan membawa beragam potensi baik (fitrah) membutuhkan bimbingan dan arahan yang baik dan konsisten. Upaya tersebut perlu dilakukan agar fitrah yang dimilikinya mampu mencapai titik optimal. Oleh karenanya, tidak dapat dipungkiri besarnya peran orang tua dalam mencetak generasi yang berkualtas melalui pendidikan yang baik, yang bernafaskan ajaran-ajaran Islam.

\section{Paradigma Pendidikan Anak dalam Keluarga di Era Digital}

Islam memandang bahwa peran orang tua dalam pendidikan anak sangatlah besar. Hal tersebut sebagaimana termuat dalam hadits Nabi Saw, yang diriwayatkan Imam Bukhari dari Abu Hurairah r.a. Nabi Saw bersabda:

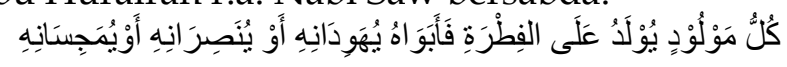

Anak dilahirkan dalam keadaan fitrah, orang tuannyalah yang menjadikan dia Yahudi atau nasrani, atau Majusi

Hadits di atas menunjukan betapa besarnya peran orang tua terhadap pendidikan anaknya. Seorang anak tumbuh dan berkembang dalam lingkungan keluarga. Waktunya banyak bersama keluarga. Setiap hari dia menyaksikan segala gerak-gerik yang dilakukan orang tua dalam keluarga. Oleh karenanya, tidak salah bila dikatakan bahwa pendidikan keluarga adalah pendidikan pertama dan utama bagi anaknya.

Dalam kaitan dengan era digital ini, orang tua perlu menyadari bahwa anak-anak masa kini dihadapakan pada tantangan zaman yang memiliki karakteristik yang berbeda dengan zaman para orang tua di masa lalu. Oleh karenanya, penting dilakukan penyesuaian terhadap pola dan pendekatan pendidikan yang digunakan karena setiap zaman memiliki problematika pendidikan yang berbeda.Ali bin Abi Thalib r.a. pernah berpesan, "didiklah anak-anak kalian agar siap menghadapi zamannya, karena mereka diciptakan untuk zaman yang berbeda dengan zaman kalian" ${ }^{28}$

Paradigma pendidikan kontekstual dalam Islambukan berarti melakukan proses perubahan secara total dalam segala aspek bahkan tujuan pendidikanya, namun lebih kepada pendekatan pendidikan yang digunakan oleh para pendidik. Oleh karenanya, kehadiran teknologi digital secara substantif tidak merubah muatan pendidikannya. Muatan pendidikan Islam sebagaimana yang disinggung di atas mencakup berbagai aspek yang mendukung pengembangan potensi fitrah anak, seperti pendidikan iman, pendidikan akhlak, pendidikan fisik, pendidikan rasio, pendidikan psikis, pendidikan sosial, dan pendidikan

${ }^{28}$ Hamruni, Konsep Edutaiment dalam Pendidikan Islam, (Yogyakarta: Bidang Akademik UIN Sunan Kalijaga, 2008),234. 
seksual. Dengan muatan pendidikan yang mengacu kepada dimensi fitrah anak tersebut harapannya dapat mengantarkan pada terbentukya individu-individu shaleh dan berkualitas.

Pemahaman orang tua terhadap anak berkaitan dengan tumbuhkembangnya penting untuk menjadi dasar pijakan bagi orang tuadalampendidikananaknya. Seorang anak berkembang mengikuti masa-masa perkembangan tertentu dan memiliki pola perkembangan serta tempo dan iramanya tersendiri. ${ }^{29}$ Pada setiap fase perkembangan anak-anak memiliki kebutuhan khusus yang harus terpenuhi. Kebutuhan itu meliputi kebutuhan biologis, rasa aman, rasa kasih sayang, rasa harga diri dan realisasi diri. Mereka memiliki perbedaan antara satu dengan yang lainnya,baikperbedaan yang disebabkan oleh faktor endogen (fitrah) maupun eksogen (lingkungan) yang meliputi jasmani, intelegensi, sosial, bakat, dan minat. ${ }^{30}$

Dalam kaitannya dengan teknologi digital, orang tua dituntut untuk mengenali media digital dan memanfaatkanya untuk kepentingan pendidikan anak. Teknologi digital sebagaimana dijelaskan di awal memiliki nilai, baik nilai positif maupun negatif. Orang tua dituntut untuk memahami sisi manfaat dan madhorotnya. Pemahaman orang tua tentang nilai dari dunia digital menjadi hal pokok yang harus disadari. Hal ini penting agar orang tua tepat dalam menyikapi perkembangan dunia teknologi. Karena era digital sejatinya bukan lagi sebuah pilihan mau atau tidak mau, bukan juga masalah siap atau tidak siap namun merupakan konsekwensi ${ }^{31}$ yang tidak dapat dihindari dari derasnya laju perkembangan teknologi yang tidak terbendung. Oleh karenanya, tidak ada pilihan bagi para orang tua saat ini kecuali mampu menguasai dan mengendalikan teknologi secara benar sesuai kebutuhan dan kemaslahatannya bagi pendidikan anak.

Tidak dapat dipungkiri memasuki era digital ini, para orang tua dihadapakan pada tantangan yang semakin berat dalam pendidikan anak. Pasalnya sebagaimana dijelaskan pada pembahasan terdahulu, teknologi informasi memiliki dua sisi yang berbeda, satu sisi menawarkan peluang bagi kemudahan pendidikan anak dengan hadirnya berbagai aplikasi pendidikan dan kemudahan akses terhadap informasi, namun disisi lain menunjukan sisi negatif yang dapat menghambat perkembangan bahkan merusak pribadi anak.

Sisi negatif dari teknologi informasi sejatinya bukan semata-mata pada perangkat teknologinya namun terletak pada konten yang terdapat di dalamnya. Hal ini karena teknologi dapat digunakan oleh siapapun dengan beragam kepentingan dan tujuan. Oleh karenanya, penting bagi orang tua untuk memahami realitas tersebut.

Di era inipara orang tua dituntut untuk memahami lingkungan dengan realitas dan kondisi yang berbeda dengan era kelahirannya. Hal ini terutama karena banyak masyarakat modern saat ini menjadikan teknologi tidak hanya sebagai media pendukung yang bersifat komplementer, namun lebih dari itu menjadikannya sebagai trend dan gaya hidup.

\footnotetext{
${ }^{29}$ Ibid., 106.

${ }^{30}$ Ibid., 107.

${ }^{31}$ Wawan Setiawan, "Era Digital dan Tantangannya," Prosiding Seminar Nasional Pendidikan, Universitas Muhammadiyyah Sukabumi (2017), 1.
} 
Lingkungan pendidikan sebagai salah satu faktor penting bagi perkembangan anak tidak lagi dapat ditafsirkan dengan lingkungan fisik face to face, tempatanakberinteraksi dengan orang lainsecarafisik yang terbatas, namun jangkauannya saat ini menjadi lebih luas dan tanpa batas. Anak-anak berbondong-bondong masuk dalam dunia maya dengan beragam media dan konten yang syarat dengan beragam kepentingan dan tujuan.

Berbagai pengaruh dan dampak negatif dari media teknologi sebagaimana dipaparkan pada pembahasan terdahulu menjadi boomerang yang mengkhawatirkan bagi pembentukan dan perkembangan pribadi anak. Oleh sebab itu, anak-anak memerlukan bimbingan dan arahan dari orang tua dalam penggunaan perangkat atau media digital secara bijaksana.32Teknologi digital seyogyanya tidak digunakan hanya sebatas untuk kemudahan dan kenyamanan, namun lebih dari itu harus memiliki muatan kebaikan dan dimanfaatkansebanyak-banyaknya untuk kepentikan pendidikan.

\section{Penutup}

Paradigma pendidikan keluarga yang dibangun di era sekarang seyogyanya memperhatikan realitas kondisi kekinian. Pendidikan kontekstual yang dimaksud bukan berarti melakukan proses perubahan secara total dalam segala aspek bahkan tujuan pendidikanya, namun lebih kepada pemahaman terhadap aspek manfaat dan dampak negatif yang terdapat dalam media digital, sehingga orang tuadapatmenerapkanpendekatan pendidikan yang tepat untuk menghasilkan generasi shaleh.

Diantaraupayapenting yang dapatdilakukan orang tua antara lain: (1) meningkatkan pemahaman orang tua terhadap potensi dan perkembangan anak; (2) memahami muatanpendidikan apa saja yang harus ditrasmisikan; (3) mengenali media digital dengan baik, baik aspek manfaat maupun dampak negatifnya; (4) mampu menggunakan media digital sebagai sarana pendidikan.

\section{Daftar Pustaka}

Faisal, Nasrun. Pola Asuh Orang Tua Dalam Mendidik Anak Di Era Digital. Jurnal An-Nisa', Volume IX Nomor 2 Desember 2016.

Hamruni. 2008. Konsep Edutaiment dalam Pendidikan Islam. Yogyakarta: Bidang Akademik UIN Sunan Kalijaga.

Hasugian, Jonner. Perpustakaan Digital dan Digital Natives, makalah yang disampaikan pada seminar dan workshop nasional Pemberdayaan Repository... di U.H. Nommensen Medan. http://repository.usu.ac.id/handle/123456789/64595 di akses pada $4 / 02 / 2019$

${ }^{32}$ Dyna Herlina S dkk, Digital Parenting: Mendidik Anak Di Era Digital, (Yogyakarta: SamudraBiru, 2018), 2. 
Herlina S, Dyna dkk. 2018. Digital Parenting: Mendidik Anak Di Era Digital. Yogyakarta: Samudra Biru.

Istiana, Purwani Gaya Belajar Dan Perilaku Digital Native Terhadap Teknologi Digital Dan Perpustakaan, dalam Prosiding Seminar Nasional:"Kreatifitas Pustakawan pada Era Digital dalam Menyediakan Sumber Informasi bagi Generasi Digital Native", (UNPAD Press,2016).

Katsir, Ibnu. Tafsir Ibnu Katsir dalam E-Book "Ayat", surat at-Tahrimayat 6. Penerbit: King Saud University.

Mardina, Riana. "Potensi Digital Natives Dalam Representasi Literasi Informasi Multimedia Berbasis Web Di Perguruan Tinggi,"Jurnal Pustakawan Indonesia Volume 11 No. 1, 2011.

Prensky, Marc." Digital Natives, Digital Immigrants Part 1".On the Horizon Vol. 9 Issue: 52001.

Setiawan, Wawan. "Era Digital dan Tantangannya".Prosiding Seminar Nasional Pendidikan, Universitas Muhammadiyyah Sukabumi, 2017.

Siaran Pers No. 53/Hm/Kominfo/02/2018 tanggal 19 Februari 2018, Tentang Jumlah Pengguna Internet 2017 Meningkat, Kominfo akan Terus Lakukan Percepatan Pembangunan Broadband, pada tanggal 24-01-2019

Suharto, Toto. 2006. Filsafat Pendidikan Islam. Yogyakarta: Ar-Ruzz.

Suwaidi, Muhammad Nur Abdul Hafizh. 2012. Prophetic Parenting: Cara Nabi Mendidik Anak. terj. Farid Abdul Aziz Qurusy. Yogyakarta: Pro-U Media.

Sya'idah, Khasnah. 2005. "Pemikiran Pendidikan Anak Abdullah Nasih Ulwan ( Disertasi Doktoral). Jakarta:Universitas Islam Negeri Syarif Hidayatullah.

Taylor, Victoria Japan to launch 'fasting' camps for Internet-addicted students, dalam diakses pada tanggal 6 Februari 2019.

Tim Kementrian Pendidikan dan Kebudayaan. 2016. Seri Pendidikan Orang Tua: Mendidik Anak di Era Digital. Jakarta: Kementrian Pedidikan dan Kebudayaan.

Tim Redaksi Majalah Swara Cita. "Anak Indonesia." Majalah Swara Cita: Generasi Digital. Digdaya Dinamika Publika, 2016.

Triastuti, Endah, Dimas Adrianto Indra Prabowo, dan Akmalia Nurul. 2017. Kajian Dampak Penggunaan Media Sosial Bagi Anak Dan Remaja. Depok: Pusat Kajian Komunikasi, FISIP Universitas Indonesia.

Ulwan, Abdullah Nasih. 2002. Pendidikan Anak Dalam Islam Jilid 1. terj. Jamaludin Miri. Jakarta: Pustaka Amani. 